\title{
ДЕРЖАВНЕ РЕГУЛЮВАННЯ ПРОЦЕСУ ТРАНСФОРМАЦЇ̈ ЕНЕРГЕТИКИ ВІД ЗАСТАРІЛОЇ МОДЕЛІ ЇЇ ФУНКЦІОНУВАННЯ ДО НОВІТНЬОЇ «НИЗЬКОВУГЛЕЦЕВОЇ» МОДЕЛІ
}

Левченко Н.M., д-р наук з держ. упр., професор, Національний університет «Запорізька політехніка», м. Запоріжжя, Україна.

Антонова Л.В., д-р наук 3 держ. упр., професор, Чорноморський національний університет імені Петра Могили, м. Миколаїв, Україна.

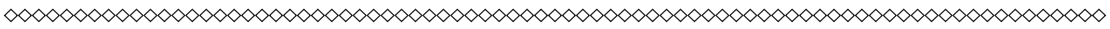

У статті акиентовано увагу на зобов'язаннях України з імплементачї Директиви 2001/80/СС про обмеження викидів деяких забруднюючихречовинуповітря від великихспалювальнихустановок. Наголошено на пріоритизації векторів ескалації енергетичного сектору економіки відповідно до Енергетичної стратегії України на період до 2035 р. та необхідності трансформації вітчизняної енергетики від застарілої моделі ї̈ функціонування до новітньої «низьковуглечевої» моделі. Констатовано критичність ситуачії щзодо технічного стану існуючих великих спалювальних установок в енергетиці України та системи передачі електроенергії, яка у сукупності з обмеженістю фінансових ресурси операторів, щзо їх обслуговують, а також значним обсягом робіт з модернізачії обладнання та тривалим часом їх виконання перешкоджають своєчасному виконанню, взятих урядом України зобов'язань щзодо зменшення викидів в атмосферу парникових газів та забруднюючих речовин. Констатовано прийняття урядом, за існуючоїможливості «дерогації», Національного плану скорочення викидів від великих спалювальних установок та визначено існуючі перешкоди на шляху його реалізаиіі. Здійснено компаративний аналіз еволюиійного 
розвитку інструментарію механізму державного регулювання енергетичного сектору економіки в Украӥні та краӥнах $С$. Акиентовано на спробах уряду Украӥни прискорити перехід до «низьковуглецевої» моделі енергетики завдяки створенню Державного фонду декарбонізації та розробиі механізму державної підтримки учасників прочесу декарбонізації. Вказано на прогалини законодавства з розробки механізму державної підтримки учасників процесу декарбонізації та наголошено на необхідності його доопрацювання. Обгрунтовано доцільність внесення доповнень до Енергетичної стратегії України на період до 2035 року «Безпека, енергоефективність, конкурентоспроможність» щчодо припинення перехресного субсидіювання, забезпечення привабливого інвестичійного клімату в енергетичному секторі економіки країни та мобілізації комтів до Державного фонду декарбонізачії, створення якого сприятиме виконанню, взятих Україною зобов 'язань щзодо зменшення викидів парникових газів та забруднення навколишнього середовища.

Ключові слова: енергетика, «зелена» енергетика, «низьковуглецева» енергетика, «озеленення» енергетики

Постановка проблеми у загальному вигляді. Локомотивом розвитку національної економіки та запорукою іiі успішної перебудови загальновизнано енергетику, пріоритетні вектори ескалації якої наразі визначено Енергетичною стратегією України на період до 2035 р. «Безпека, енергоефективність, конкурентоспроможність», затвердженою розпорядженням КМУ від 18.08.2017 р. за №605-p. [1] (далі - ЕСУ), що перед усім передбачає трансформацію енергетики від застарілої моделі їі функціонування (з домінуванням великих виробників, використанням викопного палива, неефективних мереж і т.д.) до новітньої «низьковуглецевої» моделі - моделі «зеленої» енергетики.

Характерними ознаками моделі «зеленої» енергетики є переважне використання низьковуглецевих джерел і технологій виробництва енергії, впровадження інтелектуальних систем (smart 
energy), реалізація заходів зі зниження енергоємності економіки, а також диверсифікації джерел і шляхів постачання енергоресурсів, підвищення економічної, енергетичної та екологічної безпеки, оптимізації енергетичного балансу, а отже, і створення міцного підгрунтя для сталого енергетичного майбутнього країни [1]. Тож, трансформація енергетики від застарілої моделі їі функціонування до «низьковуглецевої» ставить перед Україною нові технологічні та економічні виклики, а отже, і зумовлює потребу у формуванні нової енергетичної політики держави та розробки дієвого механізму державного регулювання процесу трансформації моделі енергетики України.

Аналіз останніх досліджень і публікацій засвідчує, що питання формуванні нової енергетичної політики держави, спрямованої на «озеленення» енергетики тривалий час не залишають байдужими ані уряд, ані науковців та практиків. Зокрема, в працях О. Булавець, В. Венгер, О. Дячук, М. Чепелєвої, Р. Подолець, Т. Саприкіної, М. Тимченко, Г. Трипольської, Р. Юхимець та ін. визначено пріоритетні вектори 3 «озеленення» енергетики, розкрито сутність механізму стимулювання використання відновлювальних джерел енергетики (далі - ВДЕ) через «зелені» тарифи тощо. Однак зі схваленням ЕСУ, реалізація якої потребує формування нової енергетичної політики держави, розробку нових та зміну існуючих законодавчих і підзаконних актів, виникає необхідність у подальших дослідженнях можливості і доцільності імплементації світового досвіду у вітчизняну практику.

Формулювання цілей статті (постановка завдання). Метою статті є чітке окреслення векторів трансформації енергетики від застарілої моделі іï функціонування до нової «низьковуглецевої» моделі та визначення дієвого інструментарію механізму державного регулювання розвитку енергетичного сектору економіки в період трансформаційних змін.

Виклад основного матеріалу дослідження. 3 підписанням та ратифікацією Угоди про асоціацію між Україною з однієї сторони та Європейським Союзом, Свропейським Співтовариством з атомної енергії та їх державами-членами з іншої сторони, Україна взя- 
ла на себе зобов'язання імплементувати Директиву 2001/80/СC [2] про обмеження викидів деяких забруднюючих речовин у повітря від великих спалювальних установок, що забруднюють повітря (далі - Директива 2001/80/СС). Проте технічний стан обладнання існуючих великих спалювальних установок в енергетиці України (кількість яких понад 220), а також значний обсяг робіт та обмежені фінансові ресурси операторів, що їх обслуговують, не дозволяють Україні вчасно виконати вимоги Директиви 2001/80/СС. Переважна більшість об'єктів енергетичного сектору економіки наразі має бути зупинена та виведена для здійснення капітального ремонту, реконструкції чи модернізації. Однак навіть тимчасове виведення 3 експлуатації більш ніж трьох енергоблоків на рік призведе до зменшення наявних потужностей в національній енергетичній системі та зниження виробітку електричної і теплової енергії, а отже, i до загроз енергетичній безпеці країни [3]. Тож, виходячи з вищевикладених причин та 3 урахуванням можливості «дерогації» або, іншими словами, тимчасового відступу від вимог, передбачених ст. 4 Директиви 2001/80/СС, урядом України прийнято графік імплементації природоохоронних заходів або, так званий, Національний план скорочення викидів від великих спалювальних установок (далі - НПСВ), затверджений розпорядженням КМУ від 08.11.2017 p. за № 796-p. [3]. Але й щодо його термінів та можливостей реалізації існує ряд сумнівів, оскільки існуючі передумови трансформації енергетики до «низьковуглецевої» моделі ії функціонування, а саме технічний стан об'єктів енергетики та системи передачі електроенергії, недосконалість законних та підзаконних актів $є$ вагомою перешкодою на шляху трансформаційних змін.

Зокрема, технічний стан системи передачі електроенергії наразі характеризуються даними, поданими на рис.1.

Основне обладнання системи передачі електроенергії виготовлено у 1950-1970-х роках. За технічними характеристиками воно поступається сучасним зразкам та обмежує інтеграцію Smart Grid, окрім того все більше потребує на ремонти. Стан розподільчих мереж електропостачання характеризується показником SAIDI (середньої тривалості відновлення електропостачання), що набагато 
вищий, ніж у країнах $\mathrm{CC}$ (рис. 2) та показником ENS (обсягу недовідпущеної електроенергії в розподільчі мережі та прямим споживачам), схильними протягом останніх років до зростання (рис. 3 ).

$$
\sum=22996,3 \mathrm{KM}
$$

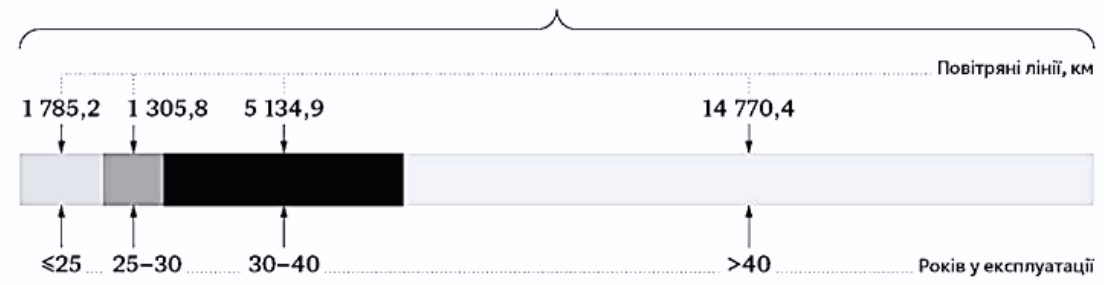

\section{$\sum=444$ одиниць}

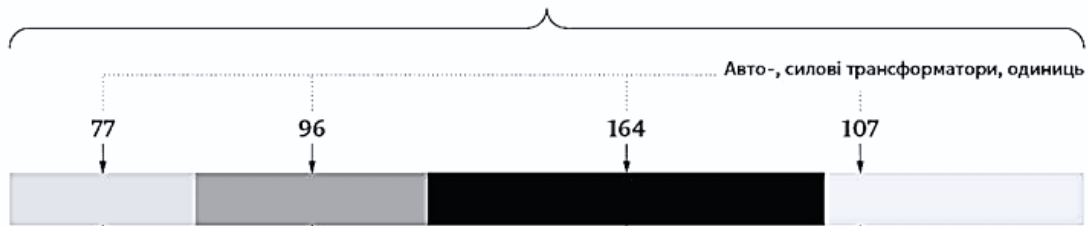

Puc. 1. Технічний стан системи передачі електроенергії в Україні [4]

SAIDI: ЄBPOПA TA УKPAIHA

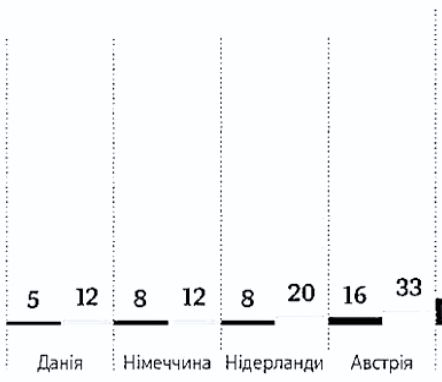

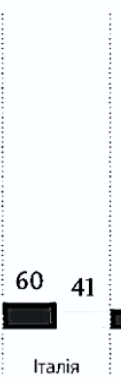

З вини компаній, Хв.
728
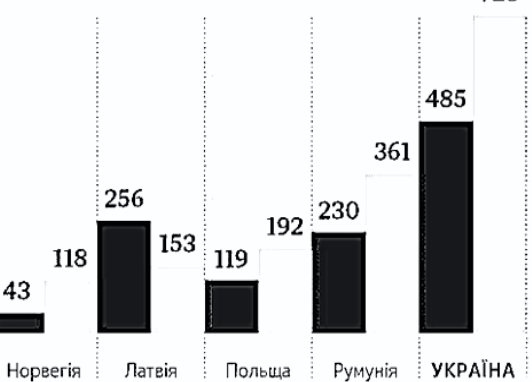

Внаслідок планових перерв, хв.

Aжepeno: HKPEKח

Puc. 2. Компаративний аналіз індексу SAIDI в країнах $\mathrm{CC}$ та Україні станом на кінець 2017 року, хвилин [4] 


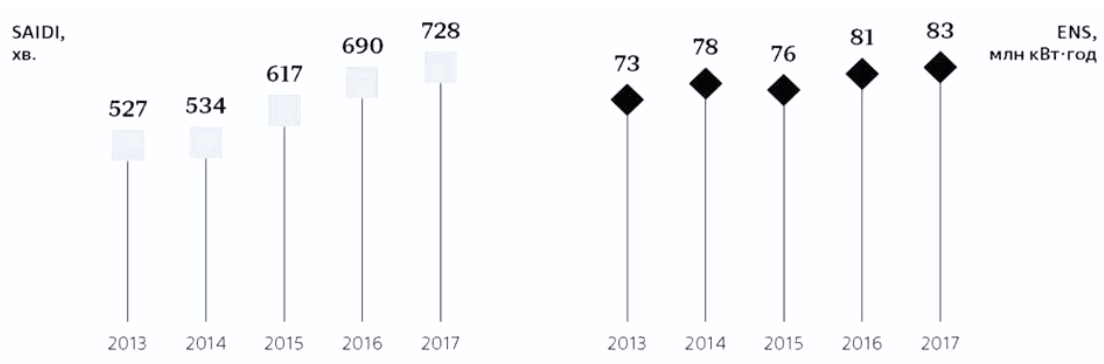

Puc. 3. Динаміка показників SAIDI та ENS в енергетичному секторі економіки України протягом 2013-2017 pp. [4]

Однак, за ЕСУ [1] передбачається досягнення у 2035 році показника $S A I D I$ на рівні нижче 150 хвилин та енерговтрат - на рівні 7,5\% проти теперішніх 11,3\% [1]. Аби досягти зазначених показників, інвестиції у розподільчі мережі мають збільшитися щонайменше у 3-4 рази від теперішніх, тобто досягти рівня не менше 180 євро/1 км [5].

Водночас за ЕСУ [1] до 2035 року передбачається збільшити частку зеленої енергетики практично у вісім разів (рис. 4), здійснити на існуючих ВСУ модернізацію обладнання та відповідно до нормативів, визначених Директивою 2010/75/СС Європейського парламенту та Ради про промислові викиди (інтегроване запобігання та контроль забруднення) від 24.11.2010 р. [6] скоротити викиди: діоксиду сірки у 20 разів (тобто на 95\% від обсягів 2012 року) до 1 січня 2025 р.; пилу - в 36 разів (тобто відповідно на 97\%) до 1 січня 2029 року; оксидів азоту в 4 рази (тобто на 72\%) до 1 січня 2034 року [5].

Визначаючи наміри скорочення викидів парникових газів, уряду України варто було врахувати той факт, що в Свропейському Союзі поточному рівню викидів забруднюючих речовин передувало: впровадження протягом майже 30 років інструментарію механізму державного регулювання енергетичного сектору економіки, який досить динамічно трансформувався; розроблення та схвалення більше десятка директив, що приходили на зміну одна одній; здійснення неодноразового перегляду нормативно-правової бази з фінансування екологічних проектів та державної підтримки енергетики. 

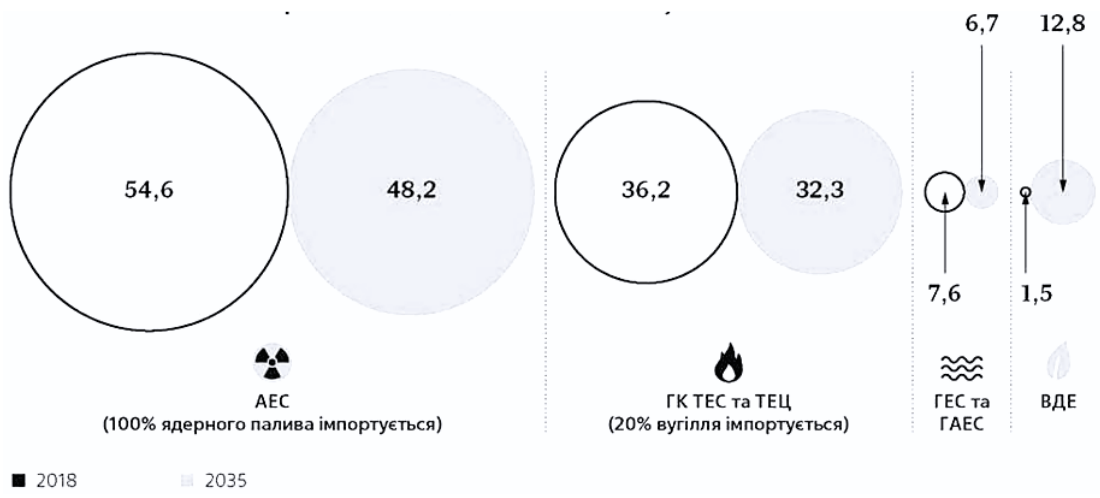

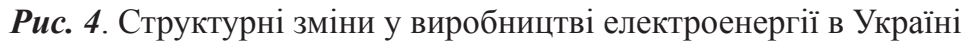
в 2035 році, \% [4]

Зокрема, починаючи з 1990-х років фінансування природоохоронних заходів в енергетиці здійснювалось за рахунок премії, що включалась до інвестиційної складової тарифів 3 електропостачання. Такий формат фінансування був зумовлений правилами функціонування ринку електроенергії, що діяли на той час. Проте, з еволюцією законодавства щодо скорочення викидів парникових газів та забруднюючих речовин в атмосферне повітря, в СС відбувся перехід до лібералізованої моделі спільного ринку електроенергії. Незважаючи на, здавалося б, відсутність прямого зв'язку між охороною навколишнього природного середовища та створенням конкурентних умов для всіх учасників ринку, прийняття Директиви 96/92/СС [7] про загальні правила внутрішнього ринку електроенергії спонукало країни-члени СС та Європейську Комісію до перегляду діючих на той час механізмів фінансування [5].

В Україні ж станом на сьогодні інструментарій механізму державного регулювання розвитку енергетичного сектору економіки не пройшов того еволюційного шляху формування регуляторної бази в енергетиці, що й і в країнах ЄС. Звісно певні спроби виконання, взятих урядом України амбітних зобов'язань щодо скорочення викидів парникових газів та основних забруднюючих речовин здійснюються в продовж останніх років, однак 
найважливішими питаннями ефективної реалізації НПСВ і досягнення визначених обсягів викидів парникових газів, що потребують на негайне вирішення лишаються питання залучення необхідних обсягів інвестицій, державної підтримки та стимулювання розвитку ВДЕ і водневої енергетики.

В країнах СС фінансування екологічної реконструкції/модернізації та техпереоснащення обладнання в енергетиці переважно здійснювалося за рахунок державної допомоги. Зважаючи ж на значний дефіцит бюджету в Україні, реалізація інструментарію державної підтримки енергетики на необхідному рівні практично не можлива. А тому, з метою прискорення переходу до моделі низьковуглецевої енергетики, Міністерство енергетики України виступило з ініціативою створення Державного фонду декарбонізації, зареєструвавши законопроект «Про внесення змін до Бюджетного кодексу України щодо запровадження державного фонду декарбонізації» від 09.11.2020 р. за №4347 [8] (далі - Проект Закону України №4347) та законопроект «Про внесення змін до Податкового кодексу України щодо перегляду ставок окремих податків» від 09.11.2020 р. за №4346 [9] (далі Проект Закону України №4346).

Зокрема, Проектом Закону України №4347 [8] передбачено внесення змін до Бюджетного кодексу України [10] (далі - БКУ) шляхом доповнення ст. $24^{59}$

створенням у складі спеціального фонду Державного бюджету України Державного фонду декарбонізації;

визначення джерелом формування Державного фонду декарбонізації коштів спеціального фонду Державного бюджету України, походженням з джерела, визначеного пунктом $13^{9}$ частини третьої ст. 29 БКУ [10], а саме 50 відсотків екологічного податку, що справляється платниками за викиди в атмосферне повітря двоокису вуглецю стаціонарними джерелами забруднення з 01.01.2021р.;

визначення напрямків спрямування коштів Державного фонду декарбонізації, а саме на співфінансування (здешевлення) проектів (заходів), що призводять до скорочення викидів двоокису вуглецю; 
визначення порядку використання коштів Державного фонду декарбонізації, невикористаних на кінець бюджетного періоду [8].

Проектом Закону України №4346 [9] передбачено внесення змін до Податкового кодексу України [12] шляхом збільшення ставки екологічного податку за викиди в атмосферне повітря двоокису вуглецю стаціонарними джерелами забруднення до 30 грн/т [9].

Концепція використання коштів Державного фонду декарбонізації передбачає виключно відшкодування частини тіла кредиту, що буде надаватись суб'єктом господарювання для впровадження заходів із декарбонізації у розмірі до $30 \%$ від тіла кредиту для позичальників-платників податку $\mathrm{CO}_{2}$, для неплатників - до 25\%. Решта коштів (70-75\%) є кредитними ресурсами під зобов'язання підприємств, що запроваджують заходи зі зменшення вуглецевого сліду [11]. Таким чином, схематичне зображення механізму державної підтримки декарбонізації коштами Державного фонду декарбонізації набуватиме наступного вигляду (рис. 5).

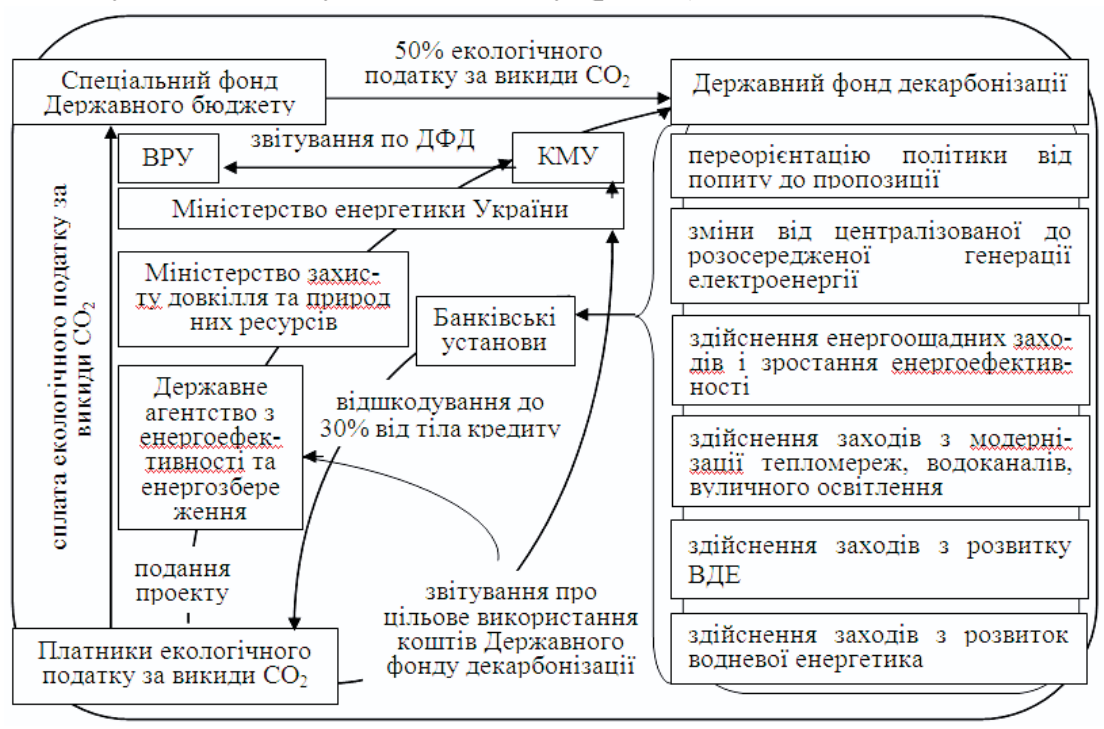

Puc. 5. Механізм державного регулювання скорочення викидів парникових газів (декарбонізації) [складено автором] 
Враховуючи світовий досвід 3 підтримки енергетичного сектору економіки, цілком підтримуємо прийняття Проектів Законів України №4346 та №4347 оскільки:

nо-перме, збільшення ставки екоподатку за викиди в атмосферне повітря двоокису вуглецю стаціонарними джерелами забруднення до 30 грн/т вважаємо цілком обгрунтованим. У зарубіжній практиці ставки вуглецевого податку значно вище, визначених Податковим кодексом України [12], про що свідчать дані табл.1;

nо-друге, країнами ЄС, зокрема, Фінляндією, Данією, Францією, Швецією та ін. 3 введенням системи вуглецевого оподаткування, одночасно запровад-жено механізм цільового використання коштів вуглецевого податку;

no-mpeтє, цільове використання коштів вуглецевого податку безперечно є стимулом як до раціонального використання енергії, так і до запровадження енергоефективних заходів та відновлюваної енергетики.

Таблиця 1

\section{Вуглецевий податок у світі [13]}

\begin{tabular}{|l|c|c|c|c|}
\hline \multicolumn{1}{|c|}{ Країна } & $\begin{array}{c}\text { Ставка } \\
\text { вуглецевого } \\
\text { податку, €/tCO }\end{array}$ & $\begin{array}{c}\text { Рік } \\
\text { імплемен- } \\
\text { тації }\end{array}$ & $\begin{array}{c}\text { Енерго- } \\
\text { ємність ВВП, } \\
\text { тне/1000\$** }\end{array}$ & $\begin{array}{c}\text { Вастка } \\
\text { в } \\
\text { енерго- } \\
\text { балансі, } \\
\%^{* *}\end{array}$ \\
\hline Швеція & 140 & 1991 & 0,15 & 53,9 \\
\hline Швейцарія & 87 & 2008 & 0,08 & 15,0 \\
\hline Фінляндія & $69-73$ & 1990 & 0,19 & 39,3 \\
\hline Норвегія & $4-56$ & 1991 & 0,12 & 69,4 \\
\hline Данія & 27 & 1992 & 0,10 & 30,8 \\
\hline Франція & 36 & 2009 & 0,12 & 15,2 \\
\hline $\begin{array}{l}\text { Велико- } \\
\text { британія }\end{array}$ & 24 & 2013 & 0,09 & 8,2 \\
\hline Ірландія & 24 & 2010 & 0,08 & 9,2 \\
\hline Словенія & 20 & 1996 & 0,14 & 22,0 \\
\hline $\begin{array}{l}\text { Південна } \\
\text { Африка }\end{array}$ & $0,4-7$ & 2015 & 0,25 & 16,9 \\
\hline
\end{tabular}


Державне регулювання проиесу трансформації енергетики від застарілої моделі ї̈ функиіонування до новітньої «Низьковуглецевої» моделі

продовження таблиці 1

\begin{tabular}{|l|c|c|c|c|}
\hline Португалія & 8 & 2014 & 0,10 & 28,0 \\
\hline Чилі & 5 & 2014 & 0,13 & 22,2 \\
\hline Латвія & 6 & 1995 & 0,18 & 37,6 \\
\hline Японія & 3 & 2012 & 0,11 & 10,1 \\
\hline Мексика & $1-3$ & 2014 & 0,12 & 7,0 \\
\hline Естонія & 2 & 2000 & 0,22 & 28,6 \\
\hline Польща & 1 & 1990 & 0,11 & 11,8 \\
\hline Україна & $0,3 *$ & 2011 & 0,30 & 6,8 \\
\hline \multicolumn{2}{|c|}{ * ставка податку за викиди двоокису вуглецю у складі екологічного } \\
\hline
\end{tabular}
податку;

** - дані по країнам світу - 2017 рік; дані по Україні - 2018 рік.

Водночас, запропонований у законопроекті №4347 механізм державної підтримки декарбонізації коштами Державного фонду декарбонізації вважаємо недосконалим. Для відшкодування частини кредиту на декарбонізацію, уряд обрав найпростіший шлях їх здійснення. Проте таке рішення слід визнати не виваженим відповідно до мети й цілей, яких прагнемо досягти внаслідок трансформації енергетики від застарілої моделі іiі функціонування до новітньої «низьковуглецевої» моделі. Причинами тому слід визнати:

- по-перше, ігнорування при відшкодуванні частини кредиту на здійснення декарбонізації Порядку здійснення моніторингу та звітності щодо викидів парникових газів, затвердженого постановою КМУ від 23.09.2020 р. за № 960 [14];

- по-друге, передбачення відшкодування частини кредиту на здійснення декарбонізації суб'єктам господарювання у сфері енергетики, розташованих не лише на підконтрольній Украӥні територіӥ;

- по-третє, неврахування при відшкодуванні частини кредиту на здійснення декарбонізації технічного стану об'єктів енергетики та стану системи передачі електроенергії;

- по-четверте, неврахування при відшкодуванні частини кредиту на здійснення декарбонізації складності реконструкції/модернізації об'єктів енергетики та системи передачі електроенергії;

- по-п'яте, неврахування при відшкодуванні частини кредиту на здійснення декарбонізації: тривалості робіт з реконструкції/ 
модернізації об'єктів енергетики; втрат виробників електроенергії, пов'язаних 3 тимчасовим виведенням об'єктів для ремонту чи модернізації; упущеної вигоди операторів установок впродовж усього періоду їх простою внаслідок виведенням для ремонту чи модернізації. Так. $з$ огляду на європейський досвід, тривалість виконання контракту на будівництво установки мокрого сіркоочищення димових газів становить від 2,5 до 3 років для блоку потужністю 200 МВт. Час зупинення блоку - приблизно 9 місяців, без урахування випробувальних і пусконалагоджувальних робіт. Якщо ж оператором ТЕС приймається рішення не встановлювати нову димову трубу, а адаптувати існуючу до нових умов роботи, період простою блоку може навіть подовжитися [5].

Висновки. Таким чином, за результатами дослідження обгрунтовано значимість законопроекту №4347 у трансформації енергетики України від застарілої моделі іiі функціонування до нової «низьковуглецевої» моделі та доведено потребу у його доопрацюванні в частині розробки механізму державної підтримки учасників процесу декарбонізації коштами Державного фонду декарбонізації шляхом зазначення прогалин, необхідних змін та доповнень. Наголошено на необхідності внесення доповнень до Енергетичної стратегії України на період до 2035 року «Безпека, енергоефективність, конкурентоспроможність» щодо припинення перехресного субсидіювання - покриття дешевої електроенергії для населення за рахунок високих тарифів для промислових та бюджетних споживачів, забезпечення привабливого інвестиційного клімату в енергетичному секторі економіки країни та мобілізації коштів до Державного фонду декарбонізації, створення якого сприятиме вчасній реалізації Національного плану скорочення викидів від великих спалювальних установок та виконанню, взятих Україною зобов'язань щодо зменшення викидів парникових газів та забруднення навколишнього середовища.

\section{Стаття надійшла до редакції: 12.10 .20}




\section{STATE REGULATION OF ENERGY TRANSFORMATION PROCESSES FROM AN OUTDATED MODEL OF ITS FUNCTIONING TO THE LATEST "LOW-CARBON" MODEL}

Nataliia Levchenko, doctor of Sciences in Public Administration, Professor, Professor of the Department of Business, Trade and Stock Exchanges, National University «Zaporizhia Polytechnic», Zaporizhia Ukraine.

Liudmyla Antonova, doctor of Sciences in Public Administration, Professor, Professor of the Department of Accounting and Auditing Black Sea National University of Petro Mohyla, Mykolaiv, Ukraine.

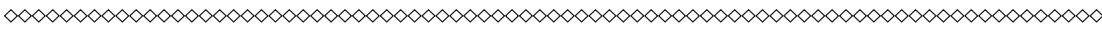

The article focuses on Ukraine's commitments to implement Directive $2001 / 80$ / EC on the limitation of emissions of certain pollutants into the air from large combustion plants. Emphasis is placed on prioritizing the vectors of escalation of the energy sector of the economy in accordance with the Energy Strategy of Ukraine until 2035 and the need to transform domestic energy from the outdated model of its operation to the latest «lowcarbon" model. The situation with the technical condition of the existing large combustion plants in the energy sector of Ukraine and the electricity transmission system is critical, which together with the limited financial resources of the operators servicing them, as well as a significant amount of equipment modernization and long-term implementation Ukraine's commitment to reduce greenhouse gas emissions and pollutants. The adoption of the National Plan for Reduction of Emissions from Large Combustion Plants by the existing possibility of «derogation» was stated by the government and the existing obstacles to its implementation were identified. A comparative analysis of the evolutionary development of the tools of the mechanism of state regulation of the energy sector of the economy in Ukraine and the EU. Emphasis is placed on the attempts of the Government of Ukraine to accelerate the transition to a «low-carbon» 
energy model through the creation of the State Decarbonization Fund and the development of a mechanism for state support for participants in the decarbonization process. The gaps in the legislation on the development of the mechanism of state support for participants in the decarbonisation process are pointed out and the need for its completion is emphasized. The expediency of making amendments to the Energy Strategy of Ukraine for the period up to 2035 "Security, Energy Efficiency, Competitiveness» to end cross-subsidization, ensure an attractive investment climate in the energy sector of the economy and mobilize funds to the State Fund for Decarbonization, which will help to reduce greenhouse gas emissions and pollution.

Keywords: energy, «green» energy, «low-carbon» energy, «greening» of energy.

\section{Received: 12.10 .20}

\section{References}

1. Rozporiadzhennia KMU Pro skhvalennia Enerhetychnoi stratehii Ukrainy na period do 2035 roku «Bezpeka, enerhoefektyvnist, konkurentospromozhnist» vid 18.08.2017 roku, №605-r. [Order of the Cabinet of Ministers On approval of the Energy Strategy of Ukraine for the period up to 2035 «Security, energy efficiency, competitiveness» of 18.08.2017, №605-r.]. zakon.rada.gov.ua. Retrieved from https://zakon.rada.gov.ua/laws/show/6052017-\%D1\%80\#Text [in Ukrainian].

2. Dyrektyva 2001/80/IeS Yevropeiskoho Parlamentu ta Rady «Pro obmezhennia vykydiv rechovyn vid velykykh ustanovok spaliuvannia, shcho zabrudniuiut povitria» [Directive 2001/80 / EU of the European Parliament and of the Council «On the limitation of emissions of substances from large combustion plants which pollute the air»]. zakon.rada.gov.ua. Retrieved from https://zakon.rada.gov.ua/laws/show/994_913\#Text [in Ukrainian].

3. Rozporiadzhennia KMU Pro Natsionalnyi plan skorochennia vykydiv vid velykykh spaliuvalnykh ustanovok, zatverdzhenyi vid 8 lystopada 2017 roku, № 796-r [Order of the Cabinet of Ministers On the National Emission 
Reduction Plan for Large Combustion Plants, approved of November 8, 2017 № 796-r]. zakon.rada.gov.ua. Retrieved from https://zakon.rada.gov.ua/laws/ show/605-2017-\%D1\%80\#Text [in Ukrainian].

4. Ohliad ekonomiky Ukrainy 2019. ASS [Review of the economy of Ukraine 2019. ACC]. publications.chamber.ua. Retrieved from http:// publications.chamber.ua/2019/Ukraine\%27s_Economic_Outlook/Country_ Profile_2019_UA.pdf [in Ukrainian].

5. Ekonomichno-obgruntovanyi pidkhid do zaprovadzhennia Natsionalnoho planu skorochennia vykydiv v Ukraini na pidstavi dosvidu skorochennia vykydiv u povitria shkidlyvykh zabrudniuiuchykh rechovyn velykymy spaliuvalnymy ustanovkamy v Yevropi [Economically sound approach to the implementation of the National Emission Reduction Plan in Ukraine based on the experience of reducing emissions of harmful pollutants into the air by large combustion plants in Europe]. Zvit IEPr NANU - IEPR report of NASU. Retrieved from https://vse.energy/docs/Report_NP\%20.pdf [in Ukrainian].

6. Dyrektyva 2010/75/IeS Yevropeiskoho parlamentu ta Rady pro promyslovi vykydy (intehrovane zapobihannia ta kontrol zabrudnennia) vid 24.11.2010 roku [Directive 2010/75 / EU of the European Parliament and of the Council on industrial emissions (integrated pollution prevention and control) of 24.11.2010]. www.kmu.gov.ua. Retrieved from https://www.kmu.gov. ua/storage/app/sites/1/55-GOEEI/\%202010_75_\%D0\%84\%D0\%A1.pdf [in Ukrainian].

7. Dyrektyva 96/92/IeS Yevropeiskoho Parlamentu ta Rady «Stosovno spilnykh pravyl dlia vnutrishnoho rynku elektroenerhii» vid 19.12.1996 roku [Directive 96/92 / EC of the European Parliament and of the Council of 19 December 1996 on common rules for the internal market in electricity]. zakon. rada.gov.ua. Retrieved from https://zakon.rada.gov.ua/laws/show/994_197\#Text [in Ukrainian].

8. Proekt Zakonu Ukrainy Pro vnesennia zmin do Biudzhetnoho kodeksu Ukrainy shchodo zaprovadzhennia derzhavnoho fondu dekarbonizatsii vid 09.11.2020 roku, №4347 [Draft Law of Ukraine On amendments to the Budget Code of Ukraine regarding the introduction of the state decarbonization fund, dated November 9, 2020 №4347]. w1.cl.rada.gov.ua. Retrieved from http:// w1.c1.rada.gov.ua/pls/zweb2/webproc4_1?pf3511=70385 [in Ukrainian]. 
9. Zakon Ukrainy Pro vnesennia zmin do Podatkovoho kodeksu Ukrainy shchodo perehliadu stavok okremykh podatkiv vid 09.11.2020 roku, №4346 [Law of Ukraine On amendments to the Tax Code of Ukraine regarding the revision of the rates of certain taxes of November 9, 2020, №4346]. ips.ligazakon.net. Retrieved from https://ips.ligazakon.net/document/JI03625A [in Ukrainian].

10. Zakon Ukrainy Biudzhetnyi kodeks Ukrainy vid 08.07.2010 roku, № 2456-VI [Law of Ukraine Budget Code of Ukraine of July 8, 2010, № 2456-VI]. zakon.rada.gov.ua. Retrieved from https://zakon.rada.gov.ua/laws/show/245617\#Text [in Ukrainian].

11. Natkha, O. (2020). Fond dekarbonizatsii dlia skorochennia SO2: efekt vartistiu 5 mlrd. hrn [Decarbonization Fund to reduce CO2: an effect worth UAH 5 billion]. ua-energy.org. Retrieved from https:/ua-energy.org/uk/posts/ fond-dekarbonizatsii-iak-instrument-znyzhennia-vykydiv-so2-chy-na-chasi [in Ukrainian].

12. Zakon Ukrainy Podatkovyi kodeks Ukrainy vid 02.12.2010 roku, № 2755-VI [Law of Ukraine Tax Code of Ukraine dated 02.12.2010, № 2755-VI]. zakon.rada.gov.ua. Retrieved from https://zakon.rada.gov.ua/laws/show/275517\#Text [in Ukrainian].

13. Ekolohichnyi podatok: stavku podatku na vykydy dvookysu vuhletsiu proponuiut zbilshyty [Environmental tax: it is proposed to increase the tax rate on carbon dioxide emissions]. Visnyk: ofitsiino pro podatky - Bulletin: officially about taxes. Retrieved from http://www.visnuk.com.ua/uk/news/100020967ekologichniy-podatok-stavku-podatku-na-vikidi-dvookisu-vugletsyuproponuyut-zbilshiti [in Ukrainian].

14. Postanova KMU Poriadok zdiisnennia monitorynhu ta zvitnosti shchodo vykydiv parnykovykh haziv vid 23.09.2020 roku, № 960 [Resolution of the Cabinet of Ministers Procedure for monitoring and reporting on greenhouse gas emissions of 23.09.2020, № 960]. zakon.rada.gov.ua. Retrieved from https://zakon.rada.gov.ua/laws/show/960-2020-\%D0\%BF\#Text [in Ukrainian].

15. Відомості про авторів / Information about the Authors

16. Левченко Наталія Михайлівна: Національний університет «Запорізька політехніка»: вул. Жуковського, 64, м. Запоріжжся, 69063, Україна.

17. Levchenko Nataliia Mykhailivna: National University «Zaporizhia Polytechnic», 64 Zhukovsky str. 69063, Ukraine. 


\section{ORCID. ORG/0000-0002-3283-6924}

\section{Email: levchenkon65@gmail.com}

Антонова Людмила Володимирівна: Чорноморський національний університет імені Петра Могили: вул. 68 десантників, 10, Миколаїв, 54003, Україна.

Liudmyla Antonova: Black Sea National University of Petro Mohyla, 68 Desantnykiv str. 10, Mykolaiv, 54003, Ukraine.

ORCID. ORG/0000-0003-2975-6453

E-mail: antonovalv77@gmail.com 